\title{
Experiências Utópicas no Território Fronteiriço do Mercosul e as Alternativas de Sustentabilidade e Desenvolvimento para o Terceiro Milênio
}

\section{Utopic Experiences on the Territory of Mercosur and Alternatives for Sustainability and Development for the Third Millennium}

\author{
José Roberto de Oliveira ${ }^{1}$
}

\section{Resumo}

Este artigo procura encontrar alternativas para possibilidades de desenvolvimento em relação a uma vida autossustentável no terceiro milênio. Parte da experiência guarani e jesuítica nas Missões, região estabelecida nas atuais áreas fronteiriças do Mercosul, demonstra que a experiência teve profunda repercussão no pensamento moderno a partir de Montesquieu e Voltaire que a chamou de "triunfo da humanidade". Foram estabelecidas, a partir da Utopia de Tomás Morus, sendo possível pelo "modo de ser" dos guaranis na sua "busca da terra sem males" e especialmente por meio de sua espiritualidade, que permite o pensamento natural de se estar vivo depois da morte física. Os jesuítas priorizavam um cristão ativo e integrado com o mundo. Em conjunto com os guaranis produziram as reduções que correspondiam a um plano quase uniforme estabelecido: a produção era maior que as necessidades e os campos estavam bem-repartidos, sem proprietários. Nenhuma cidade devia diminuir excessivamente sua população, e tampouco ser superpovoada. A virtude era a vida de acordo com a natureza. Não haviam indigentes, ninguém possuía nada, todos eram ricos. Propõe-se que este seja um caminho intermediário entre o Capitalismo e o Socialismo. Conclui-se que o planeta só será sustentável com uma sociedade fraternal e igualitária.

Palavras-chave: Experiências utópicas sustentáveis. Alternativas de desenvolvimento. Realização jesuítico-guarani.

1 Mestre em Desenvolvimento pela Universidade Regional do Noroeste do Estado do Rio Grande do Sul (Unijuí).joseroberto_deoliveira@yahoo.com.br 


\begin{abstract}
This article aims to find alternatives for development possibilities for a self-sustaining life in the third millennium. It is based on the Jesuit Guarani Missions experience in the region established in the current border areas of MERCOSUR, demonstrates that this experience had a profound impact on modern thought and Montesquieu and Voltaire called it the 'triumph of mankind'. Were established from the Utopia of Thomas More, which is possible by Guaranis 'way of being', their 'search for the land without evil and especially through their spirituality, which allows the natural thought of being alive after physical death. The Jesuits prioritized an active Christian and integrated with the world, and with the Guarani, they produced reductions that corresponded to an uniform plan established: production was greater than the needs, the fields were well distributed without owners. No city should reduce excessively population, nor to be overpopulated. The merit was a life according to nature. There were no indigent, no one owned anything, they were all rich. It is proposed that this is a middle course between Capitalism and Socialism. Concluded that the planet will be sustainable only with a fraternal and egalitarian society.
\end{abstract}

Keywords: Sustainable utopic Experiences. Alternatives for development. Jesuit-Guarani achievement. 
Este artigo é resultado de uma pesquisa bibliográfica e de campo, e nasce dentro de um contexto de estudos que analisam possibilidades de sustentabilidade e desenvolvimento alternativas às atualmente hegemônicas. A proteção do meio ambiente e dos direitos humanos ganhou uma grande importância nos últimos anos na América Latina, porém, muitas vezes, esquece-se de que já se teve experiências passadas que foram mundialmente reconhecidas como possibilidade de produção de um mundo novo que se procura.

Os imensos hiatos entre países ricos e pobres mostram a necessidade de que se produzam novas ideias a partir de pesquisas científicas nas áreas sociais e de desenvolvimento, que estejam inseridas dentro de possibilidades realizatórias sustentáveis. Encontrar um caminho de felicidade para estas nações, de certo, não está em retornar a ser nativos, índios, como poderia ser na América Latina, mas também não em torná-los europeizados. O estudo buscou encontrar um caminho intermediário a partir das experiências e ideias construídas na atual área fronteiriça do Mercosul e que de diversas formas permanecem vivas até o presente.

Entre os anos 1609 e 1768, com a criação da Província Jesuítica do Paraguai, viveu-se um modelo único na humanidade, reconhecido pela Unesco, no documento que torna as Missões Patrimônio Mundial, como "uma experiência sem precedentes na história dos povos" (Palacios; Zoffoli, 1991). Naquele período o povo guarani, que havia vivido milenarmente junto a natureza, e os jesuítas, estudantes das principais universidades europeias, conseguiram unir uma sociedade basicamente de floresta com o que havia de melhor no Barroco, por meio do papel fundamental da religião, demonstrando factível a ideia de mescla cultural para o desenvolvimento, quando cada linha de pensamento ingressa com o que tem de melhor para um fim comum. 


\section{Desenvolvimento Visto a Partir do Ser Humano}

$\mathrm{Na}$ linha de filiação discursiva a partir do ser humano e do endógeno para o desenvolvimento, Oliveira (2011) conclui que em relação às recomendações específicas às comunidades nativas da América Latina e que servem também a outras regiões deprimidas em todo o mundo, a sugestão é de que se busque o caminho da plena inclusão de seus pobres dentro da visão de “América Índia”, referido por La Torre (apud Valdéz, 2000), mostrando que o pensamento hegemônico é o da relação do homem com total respeito à natureza, compreensão que parece estabelecer uma luz para os problemas destes locais, mas também para com o planeta tão problematizado com as questões ambientais e sociais.

A teoria do desenvolvimento endógeno sustenta que cada fator e o conjunto de fatores determinantes da acumulação de capital criam um entorno no qual tomam forma os processos de transformação e de desenvolvimento das economias (Barquero, 2001). Trabalha com a ideia de que a política de desenvolvimento local é capaz de viabilizar, de forma eficiente, uma resposta local aos desafios da globalização, o que converte a teoria em um instrumento de ação. $\mathrm{O}$ autor afirma que, em última análise, são as iniciativas e o controle exercido pelos atores locais e a sociedade civil, com respostas estratégicas, que contribuem para os processos de transformação de cidades e regiões.

Para que estas ideias cresçam é preciso a introdução de modelos de Gestão Social nos ambientes locais. Tenório (2008, p. 14) afirma que “[...] o cidadão é o sujeito privilegiado de vocalização daquilo que interessa à Sociedade nas demandas ao Estado e daquilo que interessa ao trabalhador na interação com o capital". Em sociedades com interesses tão diversos dos tradicionalmente europeus, deve-se buscar com muito mais atenção as necessidades e vontades no seio da comunidade, casando com as ideias de Putnam (2000) de que a situação seria melhor se todos cooperassem para o bem comum. 
Paul Lafargue (1922), genro de Marx, no seu livro Der Jesuitenstaat in Paraguä̈, analisa que para se ter uma imaginação da terra prometida do clero católico não é necessário que soltemos de todo as rédeas da nossa fantasia e construamos um Estado do futuro, no qual poderíamos defender com boas razões o socialismo católico. Diz que precisamos sim muito mais de uma "República Cristã" que os jesuítas criaram no Paraguai. Afirma que as Missões do Paraguai são, portanto, uma realidade do idealismo cristão, e como tal devem obter a admiração do mundo.

Henri-Charles Desroches (1977, p. 2-3) sugere que se pense sobre a experiência guarani:

Uma sociedade em que $1^{\circ}$ As ferramentas e os meios de produção, em vez de pertencerem a particulares, serão propriedade coletiva social; $2^{\circ}$ As classes e o Estado serão abolidos, os trabalhadores da indústria e da agricultura formarão uma associação livre de trabalhadores que administrará economicamente a si mesma; $3^{\circ} \mathrm{A}$ economia nacional, organizada segundo um plano, basear-se-á numa técnica aperfeiçoada, tanto na indústria como na agricultura; $4^{\circ}$ Não haverá oposição entre a cidade e o campo, entre a indústria e agricultura; $5^{\circ}$ Os produtos serão repartidos segundo a regra dos velhos comunistas franceses: "De cada um, segundo as suas capacidades, para cada um, segundo as suas necessidades"; $6^{\circ}$ A ciência e as artes serão colocadas em condições suficientemente favoráveis para chegarem a seu pleno favorecimento; $7^{\circ} \mathrm{A}$ personalidade humana, isenta de preocupações da existência cotidiana e da necessidade de comprazer aos poderosos deste mundo, acabará realmente livre.

Tavares (1999, p. 63-64) diz que

A experiência missioneira teve profunda repercussão no pensamento moderno. Malgrado inimigos dos jesuítas, Voltaire, d'Alembert e Montesquieu elogiaram as missões guaranis. Voltaire as considerou um triunfo da humanidade. Montesquieu comparou o sistema missioneiro à República de Platão. Aliás, as utopias de Platão e Tomás Morus são às vezes apontadas como modelo do sistema missioneiro. Para alguns 
estudiosos, o modelo das Missões seria a Civitas Solis, de Tomás Campanella. Sabe-se que Babeuf, um radical da Revolução Francesa, admirava a experiência missioneira. Saint-Simon se inspirou nela ao preconizar um socialismo que representasse um novo cristianismo, místico e hierárquico, chamado a restaurar a unidade das idéias religiosas, solapada desde a Reforma.

Oliveira (2009, p. 202) escreve em sua pesquisa sobre o início do cooperativismo no mundo a partir das Missões:

Dentro da herança econômica é fundamental escrevermos sobre um tema que está polarizando pesquisadores de várias partes do mundo: A verdadeira história do cooperativismo começaria nas Missões. Escutando o presidente da Organização das Cooperativas do Estado do Rio Grande do Sul, Vergílio Périus, defende as idéias do estudioso Rafael Carbonell de Masy, de que é chegada a hora de resgatar a verdade sobre a origem da primeira cooperativa, surgida em 1627, na Redução Jesuítica-Guarani de Encarnación de Itapúa. Diz o nobre presidente que surge um desafio para as cooperativas da América Latina de restabelecer a verdadeira história em relação à fundação da primeira cooperativa. A cultura européia ensina como sendo a Inglaterra, através de Rochdale que teria sido o berço do cooperativismo, em 1844. No entanto, os estudos do professor apontam 1627 como o ano da fundação da primeira cooperativa em terras latinoamericanas, ou seja, agora em 2008 completando 381 anos e não 164 como contam. Aponta também que não procede a tese dos ingleses de que os princípios cooperativistas teriam sido consolidados por Rochdale, pois, desde muito tempo, tais princípios já eram praticados e sistematizados nas Missões. Prova disso, diz Périus, é a prática da livre adesão, pois o povo indígena podia optar entre o "tupambaé", propriedade comum com produção comunitária e o "abambaé”, âmbito privado de produção familiar.

Com textos dessa envergadura é factível idear sobre a possibilidade de a experiência missioneira ser alternativa para os novos caminhos da humanidade no novo milênio. 


\section{A Experiência Milenar dos Guaranis}

As duas teorias mais aceitas do aparecimento dos guaranis na América são a da passagem pelo Estreito de Bering e a vinda pela Polinésia até a chegada na América. O certo é que há cerca de 8.000 anos estavam junto ao Rio Madeira, em plena floresta amazônica, e depois foram se deslocando ao Leste e ao Sul, ocupando boa parte do território do Brasil, Paraguai e Norte da Argentina. Em relação a este tema, Palacios e Zofolli (1991, p. 71) comentam que "O índio guarani parece ter ascendência do tronco asiático, mongólico, com possíveis componentes polinésios".

Oliveira (2009) afirma que o povo guarani chegou à região hoje pertencente às áreas fronteiriças do Mercosul há cerca de 2.500 anos, momento em que ocupam os espaços de outras nações nativas que viviam no território há mais de 10 mil anos.

Quanto à “terra sem males” ou “yvy marane'y”, Soares (1997, p. 219) esclarece que: "É um espaço social, pois é onde o sistema antigo se reproduzirá, sem impedimentos. A abundância que a terra proporciona permitirá o livre exercício dos valores sociais, no qual a fartura da terra é o meio, e não o fim, para a continuidade do ñande reko [modo de ser]".

Sobre a base cultural do povo guarani, Melià (1997, p. 126) escreve: "Hoje sabemos que o máximo valor cultural dos guaranis é sua religião, uma religião da palavra inspirada, "sonhada", pelos Xamãs e "rezada" em prolongadas danças rituais [...]. A missão jesuítica não realizou, pois, uma conversão da religião guarani, senão uma substituição”.

Palacios e Zoffoli (1991, p. 181) escrevem que

Os índios guaranis eram agricultores com certas tendências sedentárias, e [...] participavam de uma das tecnologias adaptativas mais avançadas da floresta tropical. [...] ao contrário das outras parcialidades indígenas, não guarani, da região e áreas vizinhas, que continuavam no estado paleolítico de caçadores, recolhedores e nômades. 
Para dar suporte a esta pesquisa foram realizadas duas entrevistas no sentido de entender se os pensamentos e modo de ser guarani continuam presentes no seio da sociedade nativa. A primeira ocorreu no dia 21.9.2011 com o índio Mariano Aguirre, que fala sobre as questões espirituais envolvendo a vida diária:

Com relação à vida depois da morte do corpo físico, sabemos que a alma viverá, como sempre. Se foi uma boa pessoa cuidará e ajudará os que estão vivos e se foi uma pessoa má, viverá vagando e assustando os que estão por aqui.

O pajé consegue ver estas almas, tanto os bons como os que foram ruins.

Caso pensarmos forte em alguém que morreu, este poderá vir nos visitar, isto no caso do pai ou da mãe ou ainda de outros que gostávamos.

O ñande reko (modo de ser) tem na sua grande diferença a espiritualidade. Os brancos acreditam em Deus e no seu filho Jesus, mas vão as suas igrejas e rezam pedindo mais bens materiais, pedem para si, o que os distanciam dos próprios ensinamentos de seu Deus que fala de que deveriam se importar com o seu crescimento espiritual, serem irmãos, querem o bem uns dos outros, não serem individualistas, amarem-se mutuamente e cuidarem do seu mundo.

Temos um respeito às pessoas pois ouvimos todos da comunidade para tomar as decisões e respeito à natureza, pois tudo no mundo tem seu espírito. Quando colhemos uma planta para remédio (fitoterápico), conversamos com ela para que sirva ao ser humano e tiramos só o quanto precisamos.

A segunda entrevista é com o atual cacique da Aldeia Tekoa Koenju, Ariel e ocorreu no mesmo dia, quando se buscou saber sobre a importância da espiritualidade na relação guarani e ambiente:

O guarani pensa que a palavra tem uma cor para entrar no coração e tem que ter também o momento certo para ser dita. O guarani desenvolveu a vidência. Se teu pai te convida para ir à casa dele e você quando ao deitar vai meditar e tem um sonho, à noite, pode prever um acidente de carro ou alguma coisa. 
Desde criança meu avô me ensinou a caçar e pescar. Ele sempre me ensinou que tem que ter um limite, não pode exagerar, só posso caçar e pescar aquilo que posso consumir, não pode sobrar e jogar fora. Tudo tem seu dono, a natureza. Se eu estou doente e o meu avô vai tirar uma casca da árvore, tirará um pedaço só para a necessidade, e não sobras para outros, na medida.

Quando sonho, vejo as doenças e tudo que poderá ocorrer na aldeia e com isto se evita muitas coisas.

Meu avô tem 90 anos, como Carai [líder espiritual] ele consegue se comunicar com os que já morreram. Ele fala o que os espíritos falam. Quando você morre os espíritos levam ou não aquelas almas, depende de serem bons ou ruins. Por exemplo, a minha mãe no inverno na oca faz uma fogueira dentro e outra lá fora. Nós nos esquentamos lá dentro enquanto os espíritos andantes devem se esquentar lá fora, para que não se misturem dentro de casa conosco.

Alguém, como os guaranis, que pensa que continuará vivo depois da morte física é um grande diferencial em relação aos materialistas. Há uma relação homem-natureza-espiritualidade e esta é o centro da cosmologia guarani. Os que morrem vão para um outro plano e podem voltar. Os Carai sabem quando alguém importante estará para voltar.

Em relação à presença dos nativos na vida hodierna, Wolfgang Hoffmann Harnisch, na introdução de Sepp (1980, p. 18), escreve que:

Também inegavelmente se conservam, no Rio Grande do Sul, sangue e vestígios aborígines, revelando o perfil do gaúcho diversos traços indígenas inequívocos. Nesta zona é costume chamar-se guarani ao indivíduo de determinada atitude de caráter. E aquele que viajar pelas terras gaúchas, pode travar conhecimento, entre estancieiros e peões, com homens que a linguagem popular designa por guaranis.

O texto demonstra que a cultura guarani ainda está viva entre o povo da região fronteiriça do Mercosul, mesmo fato que ocorre com outras nações nativas, em outros povos latino-americanos e mundiais (Oliveira, 2009). 


\title{
O Período Jesuítico Guarani
}

Os Jesuítas consideravam o ócio um vazio que podia ser preenchido pela tentação, pelo pecado e pelo vício. Loyola, seu criador, havia compreendido a importância de um cristão ativo e integrado com o mundo (Oliveira, 2009). Sobre os primeiros jesuítas na América espanhola, Palacios e Zoffoli (1991, p. 102-103) escrevem

\begin{abstract}
Os oito primeiro jesuítas saíram de San Lucas de Barrameda em novembro de 1567 e chegaram a Callao (Lima, Peru) em abril de 1568, via Panamá. Em 1576, se instalam em Juli, nas margens do Lago Titicaca, onde fundaram um povo missioneiro e uma escola modelo, centro de adestramento para os missioneiros que chegavam da Espanha [...]. Em 1585, desde Lima (Peru) foram enviados a Santiago Del Estero, passando pouco tempo depois a Tucumám e Córdoba e logo a Asunción, onde realizam um trabalho de catequese em terra de índios e em missões volantes que não consideram adequadas... Em 1604, criam a Província Jesuítica do Paraguai, que se desliga do Peru.
\end{abstract}

Acerca das reduções, projeto de introdução da religião entre os nativos, Melià (1997) afirma que era um tipo de estrutura colonial prevista para os índios nos quais congregavam de fato vários cacicados. O novo espaço colonial urbanizado conforme os povos espanhóis, porém sem espanhóis morando neles, devia facilitar a instrução religiosa, a vida "política e humana" e a agricultura.

Sobre a chegada dos jesuítas no território guarani, Lugon (1977, p. 28) explica: "Em 1588, três padres apareceram na capital (Assunção). Aí foram recebidos como anjos, no dizer de Charlevoix. Eram o espanhol Salomino, o português Ortega e o escocês Tom Filds".

Sobre os motivos de os índios guaranis se deixarem reduzir, Melià (1997, p. 219), escreve: 
Os guaranis se vão reduzindo à vida "política e humana" com relativa facilidade porque sua comunidade pré-colonial era já uma sociedade impregnada de peculiar lógica sócio-religiosa, um pensamento altamente simbólico e bem estruturado e uma religião que vivia em seu amplo e intenso ritual, o sacramento da vida perfeita na "terra sem males", na qual a comunidade guarani, às vezes incluída com marchas e traslados físicos, está em contínua busca.

A disposição interior das reduções correspondia a um plano quase uniforme, estabelecido para todas as reduções. Lugon (1977, p. 71) comenta a frase do livro Utopia, de Tomas Morus (1997), relacionando com o seu conhecimento sobre as missões: "Quem conhece uma das cidades conhece todas, pois todas se parecem exatamente, na medida em que a natureza dos locais o permite."

Sobre o momento histórico que o mundo vivia no momento do início dos povos, Flores (1997, p. 88) destaca que

surgiram durante o esplendor do barroco, que representa uma época de inquietação com as filosofias de Leibniz, Descartes, Spinoza, Berckeley, Francisco Bacon e Blaise Pascal. Esta inquietação está simbolizada no jogo, no iluminismo e no deslumbramento das pinturas, no movimento impresso pelas linhas curvilíneas e em diagonal, buscando a integração com elementos decorativos locais, embora os cânones fossem transplantados da cultura européia. A arte tinha funções didáticas, existia para convencer e não para ser apreciada esteticamente.

Palacios e Zoffoli (1991, p. 151) informam que toda obra tem sua forma, conteúdo e significado religioso

a evangelização adquire sentido didático não só no equipamento, senão na presença de uma atmosfera espacial que sublima ornamentalmente o âmbito e apela aos sentidos, impressionando ao protagonista. Também o templo passa a ser um centro cósmico, um micromundo exclusivo, de onde as variedades cromáticas e os dourados hierarquizam as premissas 
sacras. Porém, as vezes, tudo é acessível, tangível, não há distância entre os valores superlativos e o homem comum, o indígena se sente partícipe e protagonista deste mundo que ele mesmo construiu.

Dentre os espaços das reduções é importante salientar o cotiguaçu, símbolo da fraternidade com que a sociedade cuidava dos seus necessitados, local que servia de asilo e orfanato. Além de viúvas e órfãs desamparadas, acolhia mulheres abandonadas e servia também de reformatório de mulheres. A coordenação era feita por uma anciã superior. Havia autorização para algumas saídas diárias: ir às missas e ao rosário (Oliveira, 2009).

As oficinas de produção das esculturas estavam normalmente perto da casa dos padres. Alguns povos estavam mais especializados do que outros. Quanto a isso, Palacios e Zoffoli (1991, p. 246) expressam que

houve existência comprovada de escultores nos povos missioneiros de Loreto, Itapúa, Trinidad e Corpus; de retabulistas em Santo Ângelo, São Luiz, Corpus, Mártires, Candelária, São Nicolau, Loreto e Santa Ana; de estatuários em Santiago, Santo Ângelo e Santa Ana, de entalhadores, torneros e carpinteiros em La Cruz, opinião compartida pelo Padre Furlong S.I.

Os mesmos autores dizem que são obras de arte, dignas de serem exibidas em qualquer museu. Afirmam que se trata de um estilo barroco que surgiu em plena selva e feito por mãos de índios possuidores de uma cultura neolítica e que não obstante conseguiram tantas realizações artísticas e materiais no século 17 e 18 .

A educação foi uma das prioridades do projeto. Ensinar todo aquele povo a esculpir, fazer instrumentos musicais, relógios, fundições e tantas outras realizações durante os anos 1600 e 1700 foi o verdadeiro "triunfo". O modelo da academia tão bem-usado em Florença, onde um aprendiz aprende até se tornar um mestre e daí ensinar novos aprendizes, reproduziu a capacidade da mão de obra local (Oliveira, 2009). 
Sobre a relação da Guerra Guaranítica e a construção da educação dos guaranis reduzidos, Melià (1997, p. 128) escreve: "Por sorte está a Guerra Guaranítica que vem a desmentir em grande parte a excessiva submissão dos índios à vontade dos padres; isto sim é um excelente fruto da educação".

Conforme Palacios e Zoffoli (1991, p. 381), com a expulsão dos jesuítas no ano de 1768 , termina o projeto mais original, de maior impacto, prestígio e polêmico da história missionária e de socialização cristã da Espanha na América.

Oliveira (2009) assevera que Raynal, ex-jesuíta historiador e filósofo francês, publicou uma série de obras literárias que exerceram forte influência revolucionária em toda a Europa. Perseguido, refugiou-se na Prússia e depois na Rússia, só voltando à França em 1787. Escreveu em 1770 a "Histoire Philosophique des Indes". Versa, nessa obra, sobre os trabalhos realizados nas Missões jesuíticas. O autor afirma que uma parte dos padres missioneiros, ao serem expulsos da América do Sul, teriam sido acolhidos num território que integra a Prússia ou futuramente a Rússia, e que seus ensinamentos se tornaram a base da doutrina socialista.

\section{A Utopia de Tomás Morus}

Tomás Morus (1997, p. 22-23) inicia sua narrativa sobre Utopia escrevendo sobre "homens vivendo em cidades sabiamente governadas, eis o que não se encontra em qualquer lugar”. Disserta sobre os costumes dos utopianos e que poderiam ser tomados como modelos para corrigir erros cometidos em nossas cidades, nossos países, nossos reinos.

O mesmo autor, analisando como deveriam ser tratados os que agem mal em sociedade, reforça a vertente de "instruí-los": "melhor seria providenciar-lhe meios de viver" (p. 28). Com relação à exclusão que via escreve: "Que outra coisa vocês fazem, pergunto, senão fabricarem vocês mesmos os ladrões [...]" (p. 35). 
Escrevendo sobre como são constituídas as cidades de Utopia, Morus (1997, p. 68-69) diz: "Todas são construídas segundo o mesmo plano e têm o mesmo aspecto, na medida em que o sítio o permite. A distância entre elas jamais é tão grande que não possa ser percorrida numa jornada de marcha”. "Quem conhece uma das cidades conhece todas" (p. 71).

Os utopianos conservam admiravelmente seus jardins, onde cultivam videiras, frutas, legumes e flores de tal esplendor, de tal beleza, que em nenhum outro lugar vi tamanha abundância, tamanha harmonia. Seu zelo é estimulado pelo prazer que retiram disso e também pela emulação, os diferentes bairros disputando para ver quem terá o jardim mais bem-cuidado (p. 73).

Morus (1997) diz que todo o ano elegem praticamente todos os cargos da sociedade.

O mesmo autor (1997) analisa que os campos são ocupados por pessoas das cidades que por períodos determinados vêm habitá-las. As semeaduras e a criação de animais é em número muito superior às próprias necessidades, a fim de terem um excedente a dar a seus vizinhos. "Nenhuma busca ampliar seu território, pois os habitantes se consideram antes como capatazes que como proprietários" (p. 69). Uma única atividade é comum a todos, homens e mulheres: a agricultura, que ninguém pode ignorar. "Todos a apreendem desde a infância, por um ensinamento dado na escola e pela prática, nos campos vizinhos à cidade, aonde os escolares são levados à maneira de recreação" (p. 75).

Além da agricultura cada um tem a sua profissão. Cada família confecciona sua própria roupa, cuja forma é a mesma. Os trabalhos mais fatigantes são confiados aos homens. O papel dos coordenadores é zelar para que ninguém permaneça inativo e sim se entregue a seu ofício. O dia de trabalho é dividido em três horas pela manhã e três à tarde, período que permite abundância e excesso a tudo o que indispensável. A constituição busca as 
necessidades públicas e assegurar a cada pessoa a liberação e o cultivo de sua alma, o maior tempo possível e um lazer desvencilhado de toda sujeição física. "Nisso reside para eles a verdadeira felicidade" (p. 82).

Nenhuma cidade deve diminuir excessivamente sua população, nem tampouco ser superpovoada. Se no conjunto uma cidade tem gente demais, o excedente irá compensar o déficit de outra. Há uma abundância de todos os bens que faz com que ninguém seja indigente ou mendigo.

Exportam para o estrangeiro uma grande parte de seus excedentes. O comércio lhes permite trazer os produtos que faltam. Eles próprios não fazem uso algum de moeda. Morus afirma que "a natureza, como a mais generosa das mães, pôs a nosso alcance imediato o que ela nos deu de melhor, o ar, a água, a própria terra; ao mesmo tempo, afasta de nós as coisas vãs e inúteis" (p. 92).

Seus princípios religiosos são: a alma é imortal, a bondade de Deus a destinou à felicidade; uma recompensa está reservada a nossas virtudes e a nossas boas ações; castigos a nossas más ações. A virtude é a vida de acordo com a natureza; Deus tendo nos destinado a isso. Devemos alcançar a felicidade que nos incita a levar uma vida sem tormentos, repleta de alegrias e ajudar a todos os outros; em virtude da solidariedade que nos une obter o mesmo; quer o mesmo bem para todos os seres que ela reuniu num grupo único; natureza que prescreve renunciar a benefícios que pagariam com perdas a outros.

Quanto aos mortos os utopianos pensam que:

Estão presentes quando falamos deles, invisíveis apenas ao olhar muito pouco penetrante dos mortais. [...] Assim eles vêem os mortos circulando entre os vivos, testemunhas de seus atos e de suas palavras. Essa fé na presença tutelar dos mortos lhes inspira mais confiança em seus empreendimentos e não os deixa praticar nenhum mal em segredo (Morus, 1997, p. 140). 
Observa-se que auscultar a natureza, para eles, é uma forma de honrar a Deus, transportando a ele, para sua satisfação, a admiração que ela merece. Afirma que nesta república tudo é de todos, um homem está seguro de ter o necessário contanto que os celeiros públicos estejam repletos. Não há indigentes, embora ninguém possua nada, todos são ricos (Morus, 1997).

\section{A Utopia de Clovis Lugon}

Cecchin (2009) afirma que Clovis Lugon foi o principal “Apóstolo da Utopia Missioneira” (p. 11) e quando de sua única visita aos índios em 1979 declarou que "a sociedade ideal que os filósofos procuram em todo o mundo não está na Ásia nem na Europa. Ela existiu durante 150 anos no meio da selva, em torno dos rios Paraná e Uruguai, e apesar de arrasada, ainda serve de modelo para a sociedade do futuro" (Lugon, 2009).

Lugon (1977, p. 8) acrescenta que "O genro de Karl Marx, Paul Lafargue, consagrou à República Guarani alguns capítulos da vasta história do Socialismo publicada em colaboração com Bernstein, Kautski, Plechnov [...]", e afirma que:

A república cristã dos jesuítas interessa [...] de um duplo ponto de vista. Primeiro, ela nos dá um quadro bastante exato da sociedade que a Igreja Católica esforça-se por realizar. Depois, constitui uma experiência social e, na verdade, uma das mais interessantes e mais extraordinárias que jamais tiveram lugar.

Lugon (2009) expõe:

O evangelho pregado aos homens encontrou na república dos guarani uma forma prática de cunho coletivista. Essa forma coletivista, na qual os índios colaboraram em pé de igualdade, seria o ideal a realizar-se no presente e no futuro e Deus queira que possamos, amanhã, na organização social humana, alcançar uma convergência de esforços capaz de levar 
a uma interpretação mais fraterna do homem. Uma convivência mais harmoniosa, em que aqueles que trabalham recebam a justa paga do seu esforço e em que a humanidade seja mais feliz [...] (p. 12-13).

O mesmo autor (2009) explica sua visão com relação ao comunismo e o capitalismo:

Não acredito na política dos países socialistas, como não acredito na política dos países capitalistas. Nos países socialistas o homem está muito constrangido e obrigado a fazer determinadas coisas, é um socialismo personalista, e, no capitalismo existe a mesma coisa. Se existe um pouco mais de liberdade no capitalismo, é a liberdade de ser devorado pelo mais forte. Ambas as soluções não satisfazem, pois a solução seria uma solução socialista, dentro de um princípio cristão, nem marxista, nem capitalista, oscilando para um conceito mais cristão e menos ideológico (p. 13).

Valorizando os feitos nas missões jesuíticas, Lugon (1977, p. 10) segue realçando que

A República Guarani foi, por seu lado, uma sociedade fraternal organizada segundo os princípios cristãos, no sentido em que a fraternidade estava praticamente inscrita na sua estrutura, seu regime de propriedade, seus modos de produção, e distribuição, em todas as suas instituições.

O mesmo autor afirma que o jesuíta francês, Charlevoix, que publicou em 1747 uma história em seis volumes das reduções guaranis, pensa igualmente que elas "constituem um modelo sem precedentes de sociedade cristã”.

Sobre a organização política das reduções, Lugon (1977, p. 87) apresenta a apreciação feita na revista Les Jésuites et le Secret de leur Puissance:

Esse Estado índio respondia às exigências democráticas mais modernas, visto que, longe de formar uma massa oprimida por funcionários todopoderosos, os cidadãos não viam suas liberdades entravadas senão na 
medida em que o interesse geral o exigisse; nessa república, o funcionário indígena livremente escolhido era apenas um órgão da prosperidade pública, privada de preocupações egoístas.

Lugon (1977) assevera que os corregedores e todos os funcionários eram escolhidos pelo próprio povo em eleições anuais.

Muito rapidamente as reduções constituíram o conjunto agrícola mais completo e mais bem-organizado da América. Lugon (1977, p. 138-139) descreve o pensamento de Charlevoix quando conta que os guaranis

triunfaram como que por instinto em todas as artes a que se aplicaram [...]. Basta, por exemplo, mostrar-lhes uma cruz, um candelabro, um turíbulo e dar-lhes o material para que os façam idênticos; seria difícil distinguir a obra deles do modelo que tem diante dos olhos. Fabricam e tocam muito bem todas as espécies de instrumentos de música. Viram-nos construir os órgãos mais complexos, sob a única inspeção que têm tido, assim como esferas astronômicas, tapetes à maneira da Turquia e o que há de mais difícil em qualquer tipo de manufatura.

A orientação profissional seguia o mesmo modelo do período do Renascimento, em que na academia um mestre se aplicava com seus aprendizes até que esses aprendessem e se tornassem novos mestres. Quanto à escolha da arte pelos aprendizes, Lugon, citando Charlevoix, esclarece que: "Desde que as crianças atinjam a idade de poder trabalhar, são conduzidas às diversas oficinas e fixadas naquelas para que parecem ter maior inclinação, porque estamos persuadidos de que a arte deve ser guiada pela natureza” (p. 139).

Lugon (1977, p. 158) lista uma série de bens exportáveis e de importação:

Os principais artigos exportados pelas reduções eram o mate, o fumo, o algodão, o açúcar, os tecidos de algodão e outros, os bordados, as rendas, os pavios, e círios, os objetos fabricados em torno, mesas, armários, e baús de madeiras preciosas, esculturas, peles, curtumes, e arreios de couro, 
rosários e escapulários, mel, frutas de todas as espécies, principalmente laranjas, tamarindos, tintura de cochinilha e de outras cores, cavalos, mulas e carneiros, assim como os excedentes de diversas indústrias. Todos esses produtos eram dirigidos para Buenos Aires, chegando até a Europa, e também para Corrientes, Santa Fé, Assunção e Vila Rica. Importavam produtos manufaturados e metais como ouro, prata, cobre, aço, para a fabricação de armas e decoração dos altares, peças metálicas de ferramentas, machados, relhas de arado, buris, agulhas, anzóis, facas e tesouras. Assim que as oficinas ficaram equipadas, a importação quase cessou. $\mathrm{O}$ sal vinha de Chiquitos. Seda, papel e vinho vinham da Europa.

O mesmo autor (p. 164) explicita que "O lucro comercial e financeiro, que onera economia por toda a parte, estava excluído. O motor e o regulador da agricultura, da indústria e do comércio não eram o lucro egoísta nem a concorrência, mas o bem da comunidade solidária, a sua prosperidade". Ressalta que "Ninguém se espantará, pois, pelo fato de o regime de propriedade posto em vigor na República Guarani ter sido apresentado e interpretado de maneira apaixonada e contraditória” (p. 167). Após ter estudado pormenorizadamente dezenas de autores, considerando o que estava escrito “Em L'État chrétien-social des jésuites au Paraguay, Franz Schmid quer mesmo 'fornecer a prova irrefutável' de que a República Guarani foi, não só nas grandes linhas mas até nos pormenores, uma aplicação fiel da Utopia comunista de Thomas Morus" (p. 168). Na mesma linha de pensamento, segue escrevendo o editado na Revista Lettres Edificantes:

Os bens são comuns, a ambição e a avareza são vícios desconhecidos, e não se registra entre eles litígios e nem processos de divisão [...]. Nada me pareceu mais belo do que a maneira como se provê a substância de todos os habitantes do povoado. Os que fazem a colheita são obrigados a transportar todo o cereal para os armazéns públicos (Lugon, 1977, p. 168).

O mesmo autor informa que os jesuítas haviam criado dois tipos de áreas de terras, os tupambaes, que eram os lotes coletivos ou terras de Deus, e os abambaes, que eram os lotes individuais e que cada família deveria plantar 
para o seu sustento próprio. Quanto ao trabalho, é importante refletir que as diferentes atividades e as diferenças de capacidade não davam lugar a uma escala de tratamento diferenciada. Respeitava-se o princípio natural de cada um segundo as suas capacidades e necessidades. Todos participavam equitativamente da prosperidade comum. Aquele que não queria trabalhar não deveria comer; aquele que não poderia trabalhar deveria comer. Os velhos, os doentes, os órfãos e as viúvas eram mantidos às expensas da comunidade.

A igualdade de condições para todos era um dos elementos-base de toda a formação das reduções: igualdade de nascimento, igualdade da fundação de lar, igualdade de alojamento, igualdade no ingresso à vida profissional e na vida cívica, igualdade nas condições de trabalho e nas possibilidades de lazer (Lugon, 1977).

O mesmo autor analisa a expressão de Muratori, que afirma que o segredo de tudo funcionar bem era uma liberdade bem regulada. Afirma que a liberdade era resultado diretamente da ordem estabelecida que protegia os direitos de cada um.

Clovis Lugon (p. 214), explicando sobre a educação para adultos, continua dizendo que os "Cursos de instrução e aperfeiçoamento foram instituídos para adultos que não se tivessem beneficiado de escola na infância. Chegou-se a ponto de, nos primeiros tempos, fazer repetir aos domingos, na igreja, após o serviço divino, a tabuada inteira a toda população".

Lugon (1977) expõe que a Revista Les Lettres Edificantes et Curieuses, dirigida pelos jesuítas, comparava os guaranis aos primeiros cristãos e descrevia suas comunidades como a realização ideal do cristianismo. Quanto a Voltaire, comenta que a chamou de "triunfo da humanidade" (p. 11). Expõe que o Abade Carbonell chamou as missões jesuíticas dos guaranis de "coletivismo espontâneo" (p. 12). A esse coletivismo humanista não se oporiam a moral natural, nem a tradição doutrinal, nem os ensinamentos dos papas. Destaca que o comentário do Padre Juan Fernandez, em seu Relación Historial de las Misiones de 1726, é este: "O maravilhoso surge a cada passo" (p. 13). Depois 
cita o filósofo Rayal assim: "Aí se observavam as leis, reinava uma civilidade exata, os costumes eram puros, uma fraternidade feliz unia os corações, todas as artes de necessidades estavam aperfeiçoadas" (p. 16).

\section{Conclusões}

Este artigo procura encontrar alternativas para as possibilidades humanas e sociais em relação a uma vida autossustentável no planeta no terceiro milênio, a partir da experiência guarani e jesuítica nas Missões.

Busca filiação discursiva a partir do ser humano e do endógeno para a solução dos problemas dos países pobres e que devem vir a partir do total respeito à natureza, e propõe que esta saída sirva a todo o planeta e seja oferecida por meio de modelos de Gestão Social.

Afirma que a "República Cristã" que os jesuítas criaram, projeto de cunho religioso e prático, deve servir de exemplo para os processos de sustentabilidade e desenvolvimento que a humanidade está à procura. Insiste que a experiência missioneira teve profunda repercussão no pensamento moderno, especialmente as ideias coletivistas e cooperativistas.

É demonstrado que os guaranis têm o seu máximo valor cultural na sua espiritualidade e que viviam e vivem plenamente adaptados ao planeta na floresta e nos campos da região das fronteiras do Mercosul. As crenças e visões de que o ser humano permanece vivo depois da morte em espírito e pensamento, é um dos elementos centrais do modo como percebem e respeitam a vida e como a sustentabilidade planetária deve servir para os atuais e futuros, não sendo necessário o guardar, ter mais, ser materialista, pois, sendo verdade que permanecerão vivos, não é preciso reter e usurpar tudo nesta passagem terrena, temática em interseção com as ideias que Tomás Morus (1997) relatou em Utopia, quando diz que os utopianos viam seus mortos naturalmente entre os vivos e por isso eram tão desligados das coisas materiais. 
Nesta mesma linha de ideias ficou demonstrado, por intermédio das falas de Lugon, que a República Guarani foi uma aplicação fiel da Utopia comunista de Thomas Morus, pois os bens são comuns, a ambição e a avareza são vícios desconhecidos, e não se registra entre eles litígios e nem processos de divisão, entre outros aspectos de interseção.

Tanto na Utopia quanto nas Missões, nenhuma cidade devia diminuir excessivamente sua população, e tampouco ser superpovoada, o que deve ser principalidade das políticas atuais, distante é verdade da ideia dos grandes polos urbanos que estão se formando no mundo, mas que claramente apresentam tantos déficits. Nos dois modelos, a natureza, como a mais generosa das mães, põe o que ela tem de melhor: o ar, a água, a própria terra. Devemos alcançar a felicidade que nos incita a levar uma vida sem tormentos, repleta de alegrias e ajudar a todos os outros em virtude da solidariedade que nos une para obter o mesmo. Auscultar a natureza é uma forma de honrar a Deus, transportando a ele, para sua satisfação, a admiração que ela merece. Em ambos os casos tudo é de todos; o homem está seguro de ter o necessário contanto que os celeiros públicos estejam repletos. Não há indigentes, embora ninguém possua nada, todos são ricos.

Estas designações permitem repetir que a sociedade ideal, que os filósofos procuram em todo o mundo, existiu durante mais de 150 anos nas Missões e, apesar de arrasada, ainda serve de modelo para a sociedade do futuro e que de diversas formas elas permanecem entre os nativos guaranis que persistem com estes mesmos valores.

É bastante claro que o modelo atual de relacionamento entre os países e internamente no setor do comércio, na sua forma tradicional, está levando à exclusão dos mais pobres. Nas Missões e Utopia a população obtinha os artigos sem dinheiro, nem qualquer espécie de moedas. Em modelos de pensamento atuais isto parece impraticável, porém se ocorrer uma mudança em que o centro das ideias seja a fraternidade e não o individualismo, a ambição e a avareza, quem sabe seja possível a valorização da cooperação.

A atual incapacidade de se imaginar uma atmosfera fraternal e feliz para o planeta deverá ser rompida. É crível a aplicabilidade para estas propostas, desde que o controle essencial seja exercido pelos trabalhadores, todos solidários e 
igualmente interessados na manutenção da sustentabilidade da Terra. É possível que esta seja uma das únicas soluções plausíveis para a manutenção do homem como ser vivo, visto os caminhos que o ser humano vem dando ao planeta, especialmente o eixo poluidor: Estados Unidos, Europa, Japão e China.

O segredo de tudo funcionar bem poderá ser uma liberdade bem-regulada, resultado diretamente da ordem estabelecida, protegendo os direitos de cada um, estruturado na educação, sem menosprezar a lição elementar fornecida pela coletiva República Guarani, e sem esquecer que o cidadão é o sujeito privilegiado de vocalização daquilo que interessa à sociedade nas demandas, aplicabilidade possível àqueles que apostam na Gestão Social.

Quanto à crítica ao modelo apresentado, virá sempre que apostarmos nos modelos hegemônicos e vencedores em nossa atual sociedade, geradores de grandes produtos internos brutos e poluidores. Este artigo tentou apresentar e oferecer as experiências utópicas no território fronteiriço do Mercosul, especialmente entre os séculos 17 e 18, como alternativa de sustentabilidade e desenvolvimento para o terceiro milênio do planeta. Tem-se plena consciência das impossibilidades realizatórias, pois continuamos na academia a defender os construtos europeus e estadunidenses. Esta é uma tentativa de oferecimento de um caminho a partir de nossas experiências de América Índia em seus bons momentos de conexão com o barroco europeu.

\section{Referências}

BARQUERO, Antonio Vázques. Desenvolvimento endógeno em tempos de globalização. Porto Alegre: FEE; UFRGS, 2001.

CECCHIN, Antônio. Um pedido de perdão ao povo raiz do Rio Grande. In: OLIVEIRA, José Roberto de. Pedido de perdão ao triunfo da humanidade: a importância dos 160 anos das Missões Jesuítico-Guarani. Porto Alegre: Martins Livreiro, 2009.

DESROCHES, Henri-Charles. Prefácio. In: LUGON, Clovis. A República "comunista" cristã dos guaranis 1610-1768. 3. ed. Rio de Janeiro: Paz e Terra, 1977.

FLORES, Moacyr. Reduções jesuíticas dos guaranis. Porto Alegre: EDIPUCRS, 1997. 
HARNISCH, Wolfgang Hoffmann. Introdução. In: SEPP, Antonio. Viagem às Missões jesuíticas e trabalhos apostólicos. Belo Horizonte: Itatiaia, 1980.

LAFARGUE, Paul. Der Jesuitenstaat in Paraguä̈. Stuttgart: Dietz, 1922.

LUGON, Clóvis. Lugon, a paixão pela utopia guarani. In: OLIVEIRA, José Roberto de. Pedido de perdão ao triunfo da humanidade: a importância dos 160 anos das Missões jesuítico-guarani. Porto Alegre: Martins Livreiro, 2009.

LUGON, Clovis. A República “comunista” cristã dos guaranis 1610-1768. 3. ed. Rio de Janeiro: Paz e Terra, 1977.

MELIÀ, Bartomeu. El Guarani Conquistado y Reducido-Ensayos de Etnohistória. 4. ed. Assuncion, Paraguai: Centro de Estúdios Antropológicos, 1997.

MORUS, Tomás. Utopia. Porto Alegre: L\&PM, 1997.

OLIVEIRA, José Roberto de. Análise da influência humana e social no desenvolvimento: os casos dos municípios de Caxias do Sul, Feliz e São Nicolau no Rio Grande do Sul. 2011. Dissertação (Mestrado em Desenvolvimento) - Ijuí: Ed. Unijuí, 2011.

OLIVEIRA, José Roberto de Oliveira. Pedido de perdão ao triunfo da humanidade: a importância dos 160 anos das Missões Jesuítico-Guarani. Porto Alegre: Martins Livreiro, 2009.

PALACIOS, Silvio; ZOFFOLI, Ena. Gloria y tragédia de las Misiones Guaranies Historia de las Reduciones Jesuíticas Durante los Siglos XVII y XVIII em el Río de la Plata. Bilbao: Ediciones Mensajero, 1991.

PUTNAM, Robert D. Comunidade e democracia: a experiência da Itália moderna. 2. ed. Rio de Janeiro: FGV, 2000.

SEPP, Antonio. Viagem às Missões jesuíticas e trabalhos apostólicos. Belo Horizonte: Itatiaia, 1980.

SOARES, André Luis R. Guarani: organização social e arqueologia. Porto Alegre: EDIPUCRS, 1997.

TAVARES, Eduardo. Missões Jesuítico-Guaranis. São Leopoldo: Unisinos, 1999.

TENÓRIO, Fernando Guilherme. Um espectro ronda o terceiro setor, o espectro do mercado: ensaios de gestão social. Ijuí: Ed. Unijuí, 2008.

VALDÉS, Eduardo Devés. El pensamiento latinoamericano en el siglo XX. Entre la modernización y la identidad. Tomo I, del Ariel de Rodó a la Cepal (1900-1950). Buenos Aires: Biblos, 2000. 